\title{
Utilization of a recombinant defensin from Maize (Zea mays L.) as a potential antimicrobial peptide
}

\author{
Najla Amin T. Al Kashgry ${ }^{1}$, Hussein H. Abulreesh ${ }^{2,3}$, Iman A. El-Sheikh ${ }^{1,3}$, Yaser A. Almaroai ${ }^{2,3}$, Reda Salem ${ }^{4^{*}}$ (D, \\ Ismail Mohamed ${ }^{4}$, Fatma R. Waly ${ }^{4}$, Gamal Osman ${ }^{2,3,4}$ and Mahmoud S. M. Mohamed ${ }^{5}$
}

\begin{abstract}
The search for effective and bioactive antimicrobial molecules to encounter the medical need for new antibiotics is an encouraging area of research. Plant defensins are small cationic, cysteine-rich peptides with a stabilized tertiary structure by disulfide-bridges and characterized by a wide range of biological functions. The heterologous expression of Egyptian maize defensin (MzDef) in Escherichia coli and subsequent purification by glutathione affinity chromatography yielded $2 \mathrm{mg} / \mathrm{L}$ of recombinant defensin peptide. The glutathione-S-transferase (GST)-tagged MzDef of approximately $30 \mathrm{kDa}$ in size (26 KDa GST + 4 KDa MzDef peptide) was immunodetected with anti-GST antibodies. The GST-tag was successfully cleaved from the MzDef peptide by thrombin, and the removal was validated by the TrisTricine gel electrophoresis. The MzDef induced strong growth inhibition of Rhizoctonia solani, Fusarium verticillioides, and Aspergillus niger by $94.23 \%, 93.34 \%$, and $86.25 \%$, respectively, whereas relatively weak growth inhibitory activity of $35.42 \%$ against Fusarium solani was recorded. Moreover, strong antibacterial activities were demonstrated against $E$. coli and Bacillus cereus and the moderate activities against Salmonella enterica and Staphylococcus aureus at all tested concentrations $(0.1,0.2,0.4,0.8,1.6$, and $3.2 \mu \mathrm{M})$. Furthermore, the in vitro MTT assay exhibited promising anticancer activity against all tested cell lines (hepatocellular carcinoma, mammary gland breast cancer, and colorectal carcinoma colon cancer) with $I_{50}$ values ranging from 14.85 to $29.85 \mu \mathrm{g} / \mathrm{mL}$. These results suggest that the recombinant peptide MzDef may serve as a potential alternative antimicrobial and anticancer agent to be used in medicinal application.
\end{abstract}

Keywords: Zea mays I., Antimicrobial, Defensin, Recombinant, Heterologous expression

\section{Introduction}

The higher plants are experiencing a diverse array of biotic stresses such as insects, herbivores as well as diseases caused by phytopathogenic bacteria and fungi throughout their lives in the natural environment. These different factors decrease plant productivity due to physical damages and physiological and molecular changes they cause on the growth and development of plants (Singh et al. 2020). To counter the invasions of

\footnotetext{
*Correspondence: redasalem80@gmail.com; redasalem@ageri.sci.eg

${ }^{4}$ Agricultural Genetic Engineering Research Institute (AGERI), ARC, Giza 12619, Egypt

Full list of author information is available at the end of the article
}

phytopathogens, plants have an enormous variety of secondary metabolites involved in distinctive innate defense mechanisms, pathogenesis-related proteins in plant defense mechanisms, and plant defensins (Dixon 2001; Abdelmohsen et al. 2020; Mostafa et al. 2009; Parisi et al. 2019; Yehia et al. 2020).

The $\alpha$-defensins, one group of plant defensins, are small cationic peptides with a molecular weight of approximately $5 \mathrm{kDa}$, which belong to the family of antimicrobial peptides (AMP) and adopt an amphipathic structure with a wide range of biological functions such as antibacterial, antifungal, antiviral, and anticancer activity without toxicity to mammalian cells
Springer Open (c) The Author(s) 2020. This article is licensed under a Creative Commons Attribution 4.0 International License, which permits use, sharing, adaptation, distribution and reproduction in any medium or format, as long as you give appropriate credit to the original author(s) and the source, provide a link to the Creative Commons licence, and indicate if changes were made. The images or other third party material in this article are included in the article's Creative Commons licence, unless indicated otherwise in a credit line to the material. If material is not included in the article's Creative Commons licence and your intended use is not permitted by statutory regulation or exceeds the permitted use, you will need to obtain permission directly from the copyright holder. To view a copy of this licence, visit http://creativeco mmons.org/licenses/by/4.0/. 
(van der Weerden and Anderson 2013). In general, the structure of defensins is characterized by conserved cysteine-rich peptides with the stabilized tertiary structure of the folded $\alpha$-helix and $\beta$-sheet compacted by three to four intramolecular disulfide bonds (Lacerda et al. 2014). The defensin molecules are chemically stable because their compacted structure provides the advantage of resisting extreme temperatures and protease degradation (Rodríguez-Decuadro et al. 2019).

The similar structure of defensins was conserved in invertebrate and vertebrate $\beta$-defensins. The $\beta$-defensins are also involved in the defense system of vertebrates, exhibit a wide range of antimicrobial activities and share similar structures, $\alpha$-helix, and $\beta$-sheet, but with a different topology compared to $\alpha$-defensins (Montero-Alejo et al. 2012; Shafee et al. 2016).

Protein sequence analysis of different plant defensins revealed the significant amino acid variability except for the cysteine peptides and few other residues, but conservation of their three-dimensional structures was noticeable (Lacerda et al. 2014; Parisi et al. 2019).

Gene expression analysis of plant defensins indicated that genes are either constitutively expressed or up-regulated in response to biotic/abiotic stresses in all plant tissues or specific plant organs (Noonan et al. 2017; Parisi et al. 2019). Recently, high-level expression of different defensin recombinant proteins has been reported. Hence, large-scale production is feasible (Guillén-Chable et al. 2017; Rodríguez-Decuadro et al. 2019).

Although many sequences of plant defensins are available, relatively few ones have been characterized to date. Therefore, in this study, MzDef, a maize defensin peptide, was heterogeneously expressed, and in vitro antimicrobial activities against phytopathogenic microorganisms as well as anticancer activities were evaluated.

\section{Materials and methods}

\section{Plant seeds, bacterial and fungal strains}

The seeds of Egyptian maize hybrid cultivar Gz 168 were kindly provided by the Maize Department, Field Crops Research Institute, ARC, Giza, Egypt. The reference fungal strains used in this study were obtained from Mycological center, Assuit University, Egypt; Fusarium solani AUMC 10391, Fusarium verticillioides AUMC 2652.1, Rhizoctonia solani AUMC 6594, and A. niger AUMC 4301. The bacterial strains were obtained from Microbiological Resources Center (Cairo Egypt); Bacillus cereus EMCC 1006, Staphylococcus aureus EMCC 1351, Salmonella enterica EMCC 1038 and Escherichia coli ATCC 25922 from the American Type Culture Collection (ATCC).
Isolation, cloning, and expression of the defensin coding sequence from maize

Total genomic DNA was isolated from leaf tissues (10-20 mg) of Gz 168 hybrid cultivar of Egyptian maize (Zea mays L.) by CTAB method (Guzmán et al. 2020). A pair of degenerate primers, forward: 5'-ACTAGC AKAYCTTCTTGCAGA-'3, and reverse: 5'-GATGGC KCYGTCTCGWCG-'3, was designed, according to the putative defensin sequence of the maize available in the GenBank database using the Lasergene software, MegAlign version 4.0 and primer select version 4.0.

$P f u$ DNA polymerase-generated PCR products were cloned into the PJET1.2/blunt cloning vector (Thermo Fisher Scientific, CA, USA) according to the manufacturer's instructions. The sequence (GenBank Acc. No.: MT621394) of defensin gene isolated from Egyptian maize was previously determined and characterized (Amin et al. 2021). Upon the obtaining sequence, a pair of specific primer was designed (sense: 5'- CGCGGA TCCAGCAGCAGCAACTGCGCC- $3^{\prime}$, and the antisense: 5' - CCGCTCGAGCTAGCAGTTCTTGCAGAA GC-3' flanked by BamHI and XhoI recognition sites (italic), respectively) for subcloning into pGEX-4 T-1 prokaryotic expression vector. The defensin coding sequence was inserted in-frame to be fused with GSTtagged protein to facilitate the further purification (Salem et al. 2019a; El-Gaied et al. 2020).

\section{Heterologous expression of the MzDef protein}

The pGEX-4 T-1 harboring recombinant defensin (pGEX-4 T-1-Def) was transformed into the BL21 (DE3) E. coli strain (Elgaied et al. 2017; Elmenofy et al. 2020a). Positive colonies were selected on the basis of their growth on Luria-Bertani (LB) agar plates supplemented with $50 \mu \mathrm{g} / \mathrm{mL}$ ampicillin. The $5 \mathrm{~mL} \mathrm{LB}$ medium containing ampicillin was inoculated with a single isolated colony and grown overnight at $37^{\circ} \mathrm{C}$. The expression of the GST-defensin fusion was induced by the addition of $0.1 \mathrm{mM}$ IPTG. The bacterial pellet was collected by centrifugation, and the recombinant protein was batch purified with Glutathione Sepharose 4B resin (Sigma, St Louis, USA). In an overhead shaker, the filtered bacterial lysate was incubated with $2 \mathrm{~mL}$ of glutathione Sepharose and left overnight at $4{ }^{\circ} \mathrm{C}$. The unbound proteins were washed twice with $10 \mathrm{~mL}$ of GST binding buffer, followed by two washes with $10 \mathrm{~mL}$ of GST binding buffer containing 1\% Triton X-100 to remove nonspecifically bound proteins. The bound recombinant GST-defensin peptide was eluted with $1 \mathrm{~mL}$ of elution buffer $(50 \mathrm{mM}$ Tris- $\mathrm{HCl}$ $\mathrm{pH}$ 8.0, $400 \mathrm{mM} \mathrm{NaCl}$, and $10 \mathrm{mM}$ reduced glutathione). The N-terminal GST-tag was cleaved by overnight digestion of thrombin, and then the purity of the recombinant 
protein was analyzed by Tris-Tricine gel electrophoresis, and its concentration was estimated by Bradford assay.

\section{Western blot analysis}

To confirm the purification of the defensin-GST fusion protein and to determine the cleavage of the GST-tag from defensin, $2 \mu \mathrm{g}$ of the purified protein was separated in a $15 \%(\mathrm{w} / \mathrm{v})$ Tris-Tricine gel. After electrophoresis, proteins were stained with Coomassie R-250 in 10\% ethanol (v/v) and $50 \%$ acetic acid (v/v), followed by destaining with $12.5 \%(\mathrm{v} / \mathrm{v})$ isopropanol and $12 \%(\mathrm{v} / \mathrm{v})$ acetic acid. The separated proteins were electro-transferred to a polyvinylidene difluoride membrane (PVDF, Thermo Scientific, US). The antibodies against GST protein were used as a primary antibody. Anti-mouse-Alkaline Phosphatase Sigma-Aldrich (St. Louis, MO) was used as a secondary antibody. Nitro blue tetrazolium chloride (NBT) and 5-bromo-4-chloro-3'-indolyphosphate p-toluidine (BCIP) were used as substrates for detection (Salem et al. 2018; Salem et al. 2019b; Elmenofy et al. 2020b).

\section{Evaluation of the antimicrobial activity of the peptide MZ-Def \\ Quantitative antifungal activity}

The growth rate of fungi is presented as the percentage of fungal growth inhibition. Briefly, tests were performed in 96-well microtiter plates, each well containing $100 \mu \mathrm{L}$ of potato dextrose broth (PDB) medium, fungal spore densities of $3 \times 10^{6}$ spores $/ \mathrm{mL}$ suspension in saline with $0.05 \%$ Tween 20 , and different concentrations (0.1, 0.2, $0.4,0.8,1.6$, and $3.2 \mu \mathrm{M})$ of the purified peptide MZDef with three replicates. Wells containing no peptide served as controls. The plates were incubated in the dark at $35{ }^{\circ} \mathrm{C}$ for three days. At 24 -h intervals, absorption (A) readings at $595 \mathrm{~nm}$ were recorded and corrected by subtracting time zero readings from the sample readings. The percentage growth inhibition is defined as the ratio of the corrected $\mathrm{A}_{595}$ of the control minus the corrected $A_{595}$ of the sample over the corrected $A_{595}$ of the control multiplied by 100 (CLSI 2012).

\section{Evaluation of antibacterial activity using the microbial growth curve}

The microbial growth curve was used to test the antibacterial activity of the protein MZ-Def against different bacterial species (E. coli and S. enterica as Gram-negative and S. aureus, and B. cereus as Gram-positive). Briefly, the bacterial cells were cultured overnight, and on the following day, $100 \mu \mathrm{L}$ of freshly grown bacterial culture was added to $5 \mathrm{~mL}$ of LB medium. When the read at $600 \mathrm{~nm}$ reached $0.6,100 \mu \mathrm{L}$ of purified MZ-Def solution (concentration gradients of 0.1 to $3.2 \mu \mathrm{M}$ ) was added to $5 \mathrm{~mL}$ of LB growth medium (with three replicates). Finally, the read values at $600 \mathrm{~nm}$ were determined for each bacterium. Approximately $3 \mathrm{~mL}$ of LB growth medium without the purified protein MZ-Def was regarded as the negative control (with three replicates). The antibacterial activity against a given bacterial species was assessed by determining the read values at $600 \mathrm{~nm}$ after $24 \mathrm{~h}$ of incubation.

\section{Determination of the antimicrobial activity by agar well diffusion method}

Agar well diffusion assay was performed according to the bacterial protocol MO2-A12 described in the instructions by the Clinical and Laboratory Standards Institute (CLSI) (CLSI, 2015). Briefly, inoculum containing $10^{6} \mathrm{CFU} / \mathrm{mL}$ of each microbial culture was spread on nutrient LB agar plates, selected for the bacteria, with a sterile swab, as well as potato dextrose agar (PDA) plates with $5 \mathrm{~mm}$ disc, selected for the fungi. Subsequently, wells of $8 \mathrm{~mm}$ diameter were punched into the agar medium, filled with $100 \mu \mathrm{L}$ of purified MZ-Def protein in PBS (pH 7.4) with final concentrations of 0.1, 0.2, 0.4, $0.8,1.6$, and $3.2 \mu \mathrm{M}$ (three replicates for MzDef against each organism), and allowed to diffuse at room temperature for $2 \mathrm{~h}$. Wells containing PBS served as a negative control. The plates were then incubated in an upright position at $37^{\circ} \mathrm{C}$ for $24 \mathrm{~h}$ (for bacteria) and at $28{ }^{\circ} \mathrm{C}$ for $48 \mathrm{~h}$ (for fungi). PBS-containing wells acted as a negative control.

\section{In vitro cytotoxicity}

Hepatocellular carcinoma (HePG2), mammary gland breast cancer (MCF-7), and colorectal carcinoma colon cancer (HCT-116) cell lines were obtained from ATCC and holding company for biological products and vaccines (VACSERA), Cairo, Egypt. The cell lines were used to determine the inhibitory effects of the MZ-Def peptide on cell growth using MTT assay. This colorimetric test is based on the conversion of the yellow tetrazolium bromide (MTT) to a purple formazan derivative in the mitochondria of viable cells by succinate dehydrogenase. Cell lines were grown in RPMI-1640 medium (Sigma co., St. Louis, USA) supplemented with $10 \%$ fetal bovine serum (GIBCO, UK). The antibiotics (100 units/mL penicillin and $100 \mu \mathrm{g} / \mathrm{mL}$ streptomycin) were incubated in a $5 \% \mathrm{CO}_{2}$ incubator at $37^{\circ} \mathrm{C}$. The cell lines were seeded into the wells of a 96 -well plate at a density of $1.0 \times 10^{4}$ cells per well at $37{ }^{\circ} \mathrm{C}, 5 \% \mathrm{CO}_{2}$ for $48 \mathrm{~h}$. The cells were treated with different MZDef concentrations and incubated for $24 \mathrm{~h}$; thereafter, $20 \mu \mathrm{L}$ of $5 \mathrm{mg} / \mathrm{mL}$ MTT solution was added to each well and incubated again for $4 \mathrm{~h}$. In each well, $100 \mu \mathrm{L}$ of dimethyl sulfoxide was added to dissolve the purple formazan. The quantity of formazan was measured by recording changes in absorbance (A) 
at $570 \mathrm{~nm}$ using a plate reader (Biochrom EZ 800, USA). The relative percentage of cell viability was calculated as follows: $100 \mathrm{X}\left(\mathrm{A}_{570}\right.$ of treated samples $/ \mathrm{A}_{570}$ of the untreated sample).

\section{Results \\ Cloning, heterologous expression, and purification of Mz-Def}

In this study, a defensin coding sequence was PCR amplified from total genomic DNA isolated from Gz 168 hybrid cultivar of maize (Zea mays L.). The DNA fragment was successfully amplified with the expected molecular size of approximately $245 \mathrm{bp}$ and then cloned into the PJET1.2/ blunt cloning vector. The nucleotide sequence of MzDef gene was given GenBank Acc. No.: MT621394. Sequence analysis showed that the isolated sequence consisted of a single open reading frame (ORF) of 108 bp encoding the predicted signal peptide of 34 amino acids long (Fig. 1a). Homology analysis of the deduced amino acid sequence indicated that MzDef have a common defensin tertiary structure of two $\alpha$-helix and three antiparallel $\beta$-sheets, arranged as $\alpha \beta \alpha \beta \beta$ (Fig. 1b) and stabilized by the intermolecular disulfide bonds between cysteine residues.

The recombinant MzDef fused to the GST-tag was successfully produced in E. coli from the BL21 (DE3) pLysS + RIL expression system. Total proteins were extracted from the induced E. coli BL21 after its

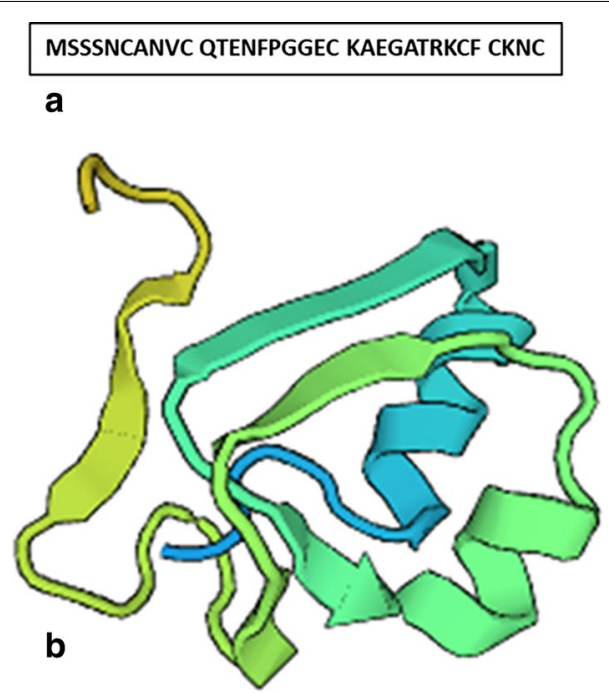

Fig. 1 Analysis of defensin peptide coding sequence isolated from Egyptian maize (Zea mays L.). The isolated sequence consisted of a single open reading frame (ORF) of $108 \mathrm{bp}$ encoding for predicted signal peptide of 34 amino acids long (a). The tertiary structure of its deduced amino acids generated by SWISS-Model homology analysis showed a common defensin tertiary structure of two a-helix and three antiparallel $\beta$-sheets, arranged as $\alpha \beta a \beta \beta$ and stabilized by the intermolecular disulfide bonds between cysteine residues (b) transformation with the recombinant pGEX-4 T-1-MzDef. The MzDef protein band fused with the GST protein was clearly observed in the time-course analysis after separating the total extracted proteins by SDS-PAGE and staining with Coomassie Brilliant Blue (Fig. 2a). The optimal expression time was $3 \mathrm{~h}$ after induction that led to produce a significant amount of fusion protein, and longer induction time did not result in any substantial increase in yield (Fig. 2a). Purification of the recombinant peptide by glutathione affinity chromatography yielded $2 \mathrm{mg} / \mathrm{L}$ of the purified Mz-Def peptide emerged as a clear band of approximately $30 \mathrm{kDa}(26 \mathrm{KDa}$ GST $+\sim 4 \mathrm{KDa}$ MzDef peptide). The GST-tag was successfully cleaved from the MzDef peptide by thrombin, and the purification was validated by Tris-Tricine gel electrophoresis.

\section{Immunodetection of the recombinant MzDef fusion protein}

In order to confirm the presence of the corresponding expressed protein, western blot was performed. In addition to the MzDef peptide after cleavage by thrombin, purified fusion proteins were resolved by SDS-PAGE on 12\% gel (Fig. 2b). Separated proteins were electroblotted onto PVDF. Antibodies against GST protein were used as a primary antibody, and the universal anti-mouse conjugated to alkaline phosphatase was used as a secondary antibody. The detection method was conducted using NBT and 5-bromo-4-chloro-3'-indolyphosphate $p$-toluidine salt (BCIP) as substrates. Western blot analysis showed that the specific signal for the expressed recombinant GST-MzDef protein can be identified by the antiGST antibody but not with the cleaved MzDef peptide (Fig. 2b).

\section{Antifungal activity of the recombinant MzDef peptide}

The antifungal activity of the recombinant MzDef was tested against several pathogenic fungi including $F$. solani, F. verticillioides, $R$. solani, and $A$. niger using a doseresponse growth inhibition assay. The antifungal activity of MzDef was assessed by incubating the fungal spores in the presence of various concentrations $(0.1,0.2,0.4,0.8$, 1.6, and $3.2 \mu \mathrm{M})$ of MzDef. The variation among technical replicates was less than $10 \%$. At the highest concentration $(3.2 \mu \mathrm{M})$ of MzDef, substantial inhibition of growth of the fungi $R$. solani, $F$. verticillioides, F. solani, and $A$. niger was observed. MzDef induced strong growth inhibition of the fungi R. solani, F. verticillioides, and A. niger by $94.23 \%, 93.34 \%$, and $86.25 \%$, respectively, whereas a relatively weak growth inhibitory activity (35.42\%) against $F$. solani was recorded (Fig. 3). Furthermore, the effect of MzDef on the biomass accumulation of the fungi $F$. solani, $F$. verticillioides, $R$. solani, and A. niger was also determined over time (at 24, 48, and $72 \mathrm{~h}$ after 
a

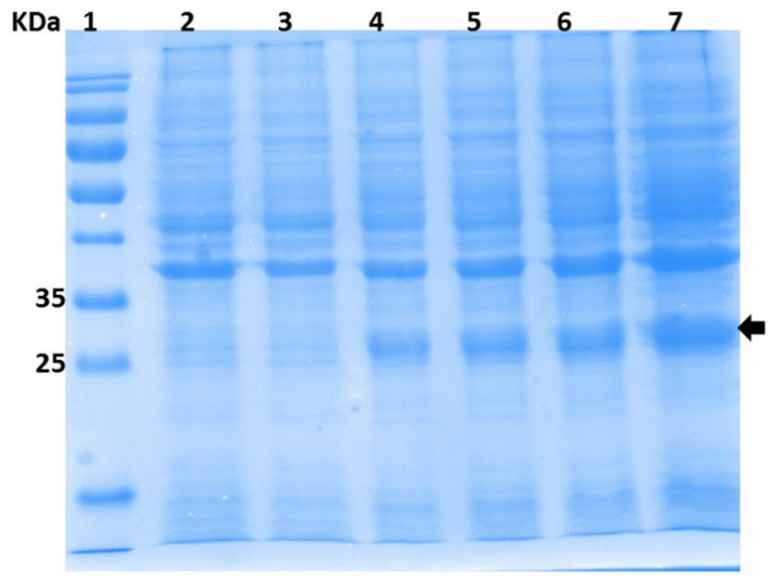

b

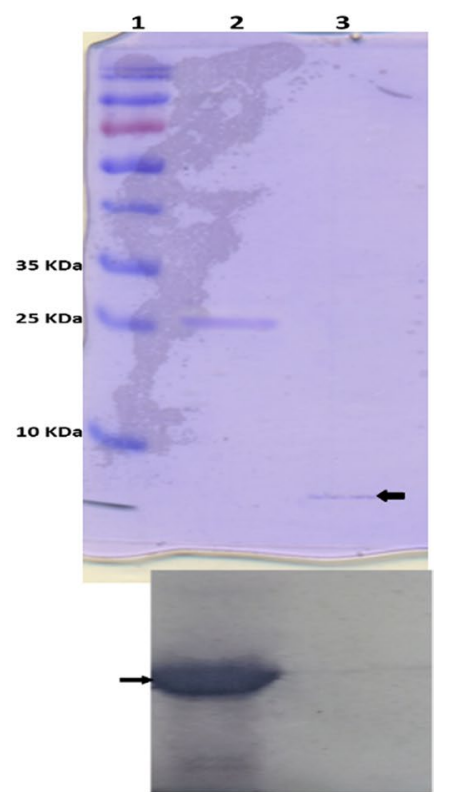

Fig. 2 SDS-PAGE followed by Coomassie blue R-250 gel staining showing: a The induction time course for MzDef in E. coli BL21 plysS (DE3) + RIL, 1: marker, 2, 3, 4, 5, 6 and 7 are the total proteins extracted from Bl21 E. coli where, 2 is negative, 3 is before induction, from 4-7 are $2 \mathrm{~h}, 3 \mathrm{~h}$, and $4 \mathrm{~h}$ post induction, respectively. $\mathbf{b}$ Purification of GST-tagged MzDef from E. coli BL21 (DE3). Coomassie stained SDS-PAGE gel showing purification of GST- MzDef. The fusion proteins are indicated by a solid arrow. The corresponding western blot analysis is shown (below) using anti-GST antibody. 1, Molecular weight marker indicated in kDa; 2, GST- MzDef fusion protein; 3, purified MzDef recombinant protein

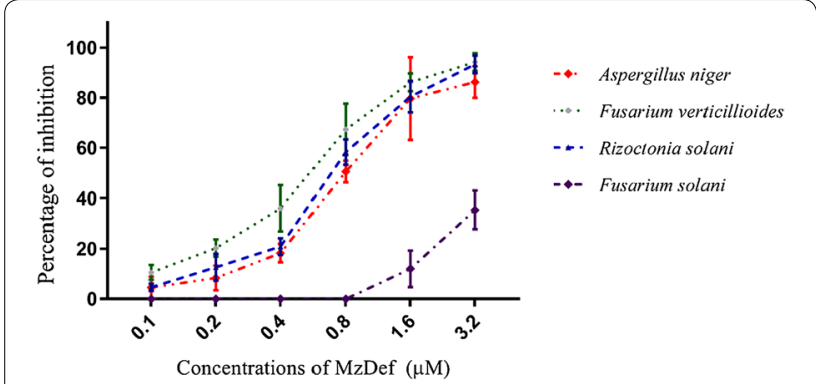

Fig. 3 Antifungal activity of MzDef on the growth of F. solani, F. verticillioides, $R$. solani, and $A$. niger. The data is represented as a percentage of fungal growth as compared to the control reactions with no MzDef peptide. The standard error for each reaction was determined

incubation) (Fig. 4). The results revealed that the biomass accumulation of all tested fungi decreased with increasing the MzDef concentration. Nevertheless, with increasing the incubation time, the inhibitory effect became less effective. The highest concentration of MzDef $(3.2 \mu \mathrm{M})$ decreased the accumulation of $A$. niger by $5.17 \%$, and at $48 \mathrm{~h}$ and $72 \mathrm{~h}$ after incubation, it decreased by $39.62 \%$ and $55.17 \%$, respectively (Fig. 4). The same level of accumulation $(5.07 \%)$ was observed after $24 \mathrm{~h}$ and $48 \mathrm{~h}$ for
F. verticillioides at the highest concentration $(3.2 \mu \mathrm{M})$ of MzDef, while a higher level of accumulation (61.03\%) was recorded after $72 \mathrm{~h}$ (Fig. 4). In contrast, a weak inhibitory effect against $F$. solani appeared when the accumulation decreased by only $68.67 \%$ after $24 \mathrm{~h}$ and disappeared afterward, and no effect was observed after $48 \mathrm{~h}$ and $72 \mathrm{~h}$ of incubation (Fig. 4). MZ-Def decreased the accumulation of $R$. solani by $4.94,10.01$, and $27.15 \%$ after 24,48 , and $72 \mathrm{~h}$ of incubation, respectively (Fig. 4).

These results were confirmed by the result of antifungal activity testing of the recombinant MzDef protein against the same species of fungi using agar well diffusion method, in which different concentrations $(0.1,0.2,0.4$, $0.8,1.6$, and $3.2 \mu \mathrm{M})$ of the recombinant MzDef protein were applied, and the relative antifungal activity with different inhibitory effects was observed for different fungal species (data not shown).

\section{Antibacterial activity of the recombinant MzDef}

The antibacterial activity of the recombinant MzDef protein against different species of bacteria was evaluated. The determination of dose-dependent growth inhibition of bacteria was performed by measuring the absorption of the cultures at $595 \mathrm{~nm}$ in the presence of different concentrations of the recombinant MzDef. 

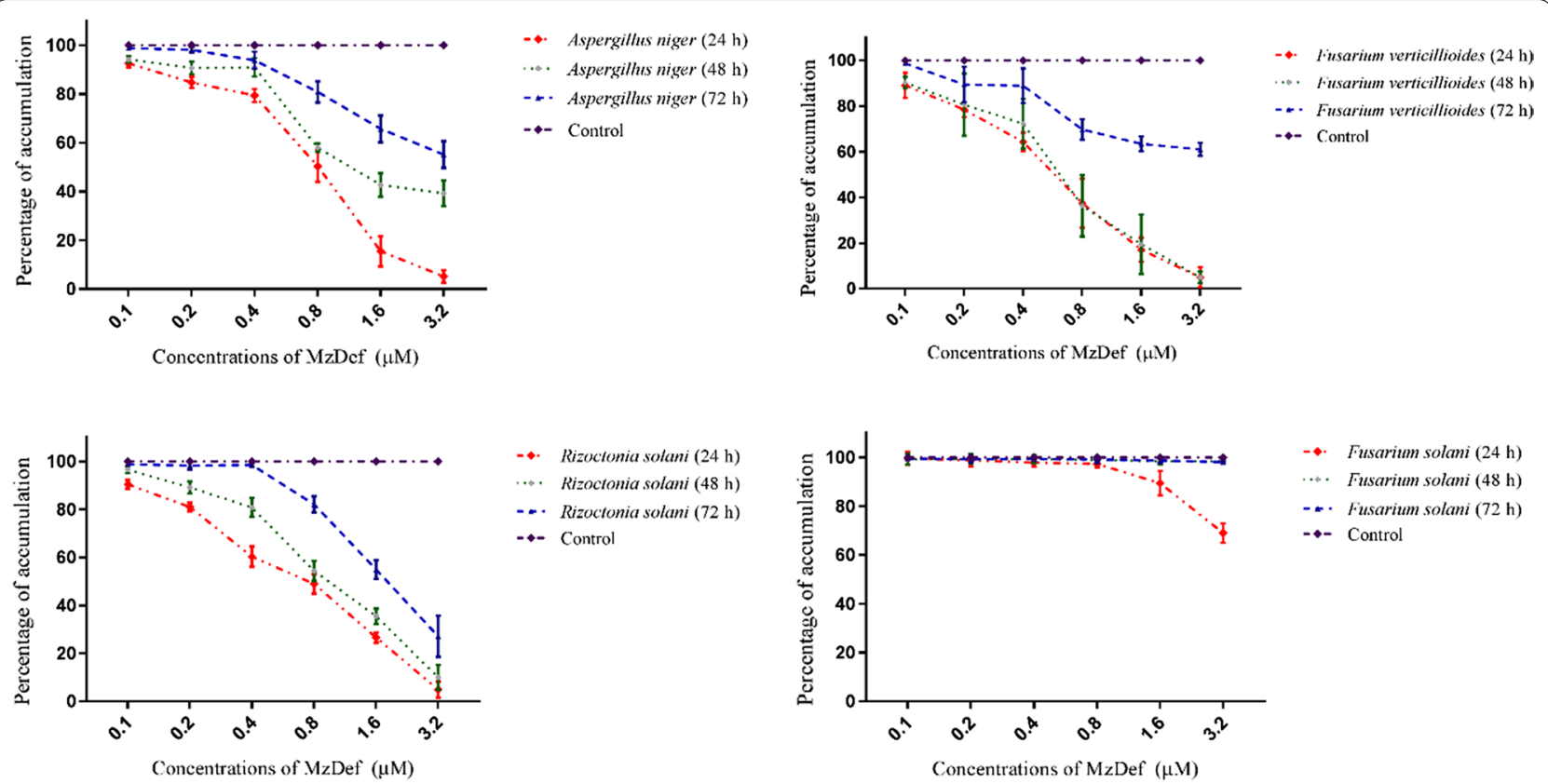

-4. Fusarium solani $(24 \mathrm{~h})$

- Rizoctonia solani $(24 \mathrm{~h})$

... Rizoctonia solani $(48 \mathrm{~h})$

-.. Rizoctonia solani $(72 \mathrm{~h})$

-๑- Control

Fusarium solani $(48 \mathrm{~h})$

-.. Fusarium solani $(72 \mathrm{~h})$

- - Control

Fig. 4 The effect of MZ-Def on the accumulation of F. solani, F. verticillioides, R. solani, and A. niger at different time interval 24, 48 to $72 \mathrm{~h}$. The data is represented as a percentage of fungal accumulation as compared to the control reactions without MzDef peptide. The standard error for each reaction was determined

The results revealed that the inhibitory activity of the purified MzDef protein had different sensitivity for different bacterial species.

The strongest inhibitory activity was observed against $E$. coli and B. cereus with the same effect, while the inhibitory effect against $S$. enterica and $S$. aureus was moderate. Furthermore, the antibacterial activity of the recombinant MzDef protein was tested against the same species of bacteria by applying different concentrations of the recombinant MzDef protein demonstrated that by increasing the concentration of the MzDef protein, the percentage of growth inhibition of bacteria was increased in all tested bacteria. At concentration $3.2 \mu \mathrm{M}$ of the MzDef protein, the inhibition percentage recorded 96, 91, 39 and 29 against E. coli, B. cereus S. enterica and S. aureus respectively (Fig. 5).

\section{Evaluation of cytotoxicity of MzDef}

The MzDef peptide was screened for an in vitro antiproliferative activity against three different cancer cell lines, including hepatocellular carcinoma (HEPG-2), mammary gland breast cancer (MCF-7), and colorectal carcinoma colon cancer (HCT-116). The tested MzDef peptide displayed promising anticancer activity against the cancer cell lines with $\mathrm{IC}_{50}$ values ranging from 14.85 to $29.85 \mu \mathrm{g} / \mathrm{mL}$ (Fig. 6).

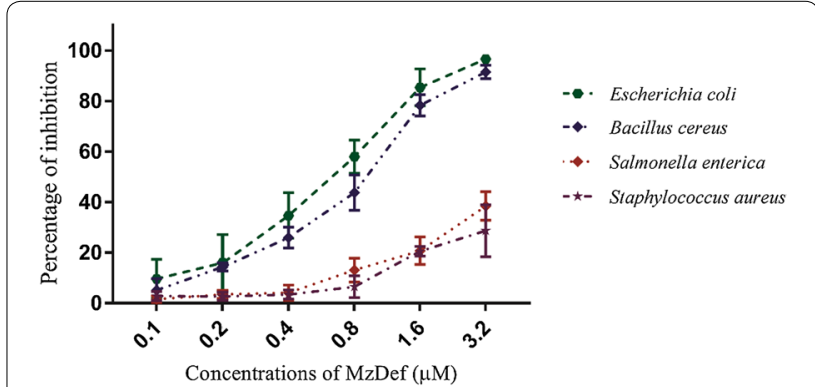

Fig. 5 Growth inhibition of E. coli, S. enterica, S. aureus, and B. cereus determining the antimicrobial activity of MzDef. The data is represented as a percentage of bacterial growth inhibition as compared to the control reactions without MzDef peptide after $24 \mathrm{~h}$ of incubation. The standard error for each reaction was determined

\section{Discussion}

Plants have an intrinsic defense system, and their innate immune systems are activated by the presence of external pathogens. This reaction is generally known as induced systemic resistance and provides a broadspectrum resistance against a vast range of unassociated pathogens. During this process, a great number of resistance products like defensins are produced to prevent the spread and expansion of pathogens (Dowd and Johnson 2018; Lacerda et al. 2014; Hultmark et al. 1980; Cociancich et al. 1994; Lay and Anderson 2005; Boman 


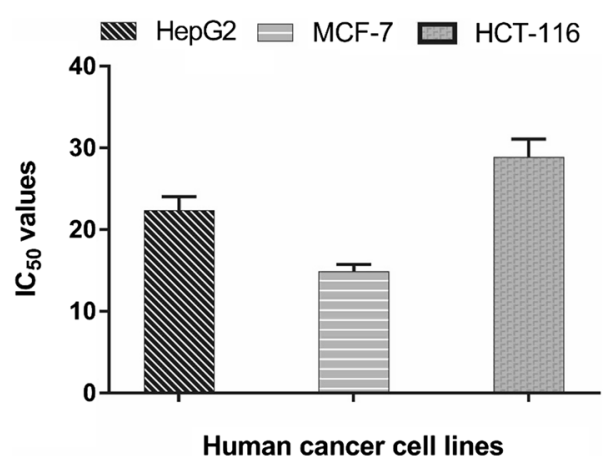

Fig. 6 The in vitro cytotoxicity of MzDef as analyzed by MTT assay against human cancer cell lines: Hepatocellular carcinoma (HEPG-2), Mammary gland breast cancer (MCF-7) and Colorectal carcinoma Colon cancer (HCT-116). The bars on the graph represent mean \pm SD of MzDef IC $C_{50}$ values of triplicate independent experiments $(n=3)$

et al. 1987; Kanost et al. 1990). Defensins are a category of cysteine-rich polypeptides with a low molecular weight of approximately $5 \mathrm{kDa}$ and have antibacterial and antifungal activities (Guillén-Chable et al. 2017; Kant et al. 2009; Cornet et al. 1995; Garcia-Olmedo et al. 2015).

In the present study, firstly, a defensin coding sequence was isolated from Egyptian maize (Zea mays L.) and cloned. Subsequently, the MzDef peptide was obtained by the expression of cloned genes in E. coli. In vitro growth inhibitory activities of the recombinant MzDef against different species of bacteria ( $E$. coli, $S$. enterica, S. aureus, and B. cereus) and fungi (F. solani, F. verticillioides, $R$. solani, and $A$. niger) were studied. The antifungal activities were confirmed by the increase in fungal biomass accumulation over time. These results are compatible with those previously reported by who found the inhibitory antifungal activity of ZmESR6, a defensin gene, isolated from other varieties of maize expressed in E. coli, against the bacterium Rhizobium meliloti, as well as the fungi Fusarium oxysporum, and Plectosphaerella cucumerina.

Furthermore, the expression of Zea mays defensin gene conferred transgenic tobacco plants enhanced tolerance to Phytophthora nicotianae var. Parasitica, and the recombinant protein displayed antifungal activity in vitro (Wang et al. 2011). A recent study reported that ZmDef124, a potential maize defensin-like protein, has inhibitory activity against both insects and fungi (Dowd and Johnson 2018). The fungal cell killing by defensins could be explained by several mechanisms such as disturbance of membrane permeability, the induced oxidative stress damage to DNA, and the induction of apoptosis and necrosis in cells (Aerts et al. 2011; Guilhelmelli et al. 2013).
In this study, MzDef was highly active against $R$. solani, $F$. verticillioides, and $A$. niger but was relatively effective against $F$. solani. The required concentration of plant defensins for inhibition of the growth of bacteria or fungi depends on the bacterial and fungal species and the plant defensing (Parisi et al. 2019; Wei et al. 2019).

In this study, MzDef demonstrated strong antibacterial activity against $E$. coli and B. cereus and moderate activity against $S$. enterica and $S$. aureus at all tested concentrations. The antibacterial activity is not a common feature of plant defensins; specific antibacterial activities against some species of bacteria have been reported (Parisi et al. 2019; Zhang and Lewis 2006). A recombinant mungbean defensin VrD1 was previously demonstrated to exhibit antibacterial activities against Staphylococcus epidermidis and Salmonella typhimurium (Chen et al. 2005). The substantial antimicrobial activities of defensins against bacteria and more than 40 different species of plant pathogens have been reported (Lay and Anderson 2005; Carvalho and Gomes 2009). For the defensins from maize, antibacterial activities against the Gram-positive plant pathogen Clavibacter michiganensis and the nitrogen-fixing bacterium Rhizobium meliloti were recorded (Balandin et al. 2005).

Moreover, eukaryotic defensins also exhibit anticancer activities (Lay and Anderson 2005, Guzmán-Rodríguez et al. 2016). In this study, the MzDef peptide was screened for an in vitro anti-proliferative activity against three different cancer cell lines, including hepatocellular carcinoma (HEPG-2), mammary gland breast cancer (MCF-7), and colorectal carcinoma colon cancer (HCT116). The tested MzDef peptide displayed promising anticancer activity against the cancer cell lines with $\mathrm{IC}_{50}$ values ranging from 14.85 to $29.85 \mu \mathrm{g} / \mathrm{mL}$.

The search for appropriate analogs as antibiotics has been the subject of several studies. Defensins have shown to be a useful alternative to antibiotics due to their unusual antibacterial function and the inability of some bacteria to develop antimicrobial resistance (Lay and Anderson 2005).

In this study, the full-length gene encoding MzDef, isolated from $\mathrm{Gz} 168$ hybrid cultivar of local maize, was successfully cloned and expressed using prokaryotic systems. The MzDef peptide was purified to homogeneity, and the purity was confirmed by western blot analysis. The MzDef exhibited enhanced antibacterial and antifungal activities against different bacterial and fungal pathogens.

\footnotetext{
Acknowledgements

The authors are grateful to king Abdulaziz City for Science and Technology (KACST) for funding this research.
} 


\begin{abstract}
Authors' contributions
The authors contributed to the work done in the manuscript as follows: All authors participated in the design, interpretation of the studies and analysis of the data and review of the manuscript; NATAK, conducted the laboratory experiments. GO and MSMM presented the data in table and graphs and prepared the preliminary version of the manuscript. HHA, IAE-S, revised the experimental design, guided the data analyses and interpretation and manuscript revision. RS, IM, guided the laboratory experiments, helped in the preparation of the first version of the manuscript and analysis of the experimental data. FRW, YAA, MSMM determined the study topic, data interpretation and final revision of the manuscript. All authors read and approved the final manuscript.
\end{abstract}

\section{Funding}

This work was funded by Research and Development Grants Program for National Research Institutions and Centers (GRANTS), Graduate ResearchProgram, King Abdulaziz City for Science and Technology (KACST), Riyadh, Kingdom of Saudi Arabia, grant no: 1-18-01-007-0022.

\section{Availability of data and materials}

All relevant data are within the manuscript.

Ethics approval and consent to participate

Not applicable.

\section{Consent for publication}

Not applicable.

\section{Competing interests}

The authors declare that they have no competing interests.

\section{Author details \\ ${ }^{1}$ Biology Department, College of Science, Taif University, Taif, Saudi Arabia. \\ ${ }^{2}$ Department of Biology, Faculty of Applied Science, Umm Al-Qura University, Makkah, Saudi Arabia. ${ }^{3}$ Research Laboratories Center, Faculty of Applied Science, Umm Al-Qura University, Makkah, Saudi Arabia. ${ }^{4}$ Agricultural Genetic Engineering Research Institute (AGERI), ARC, Giza 12619, Egypt. ${ }^{5}$ Department of Botany and Microbiology, Faculty of Science, Cairo University, Giza 12613, Egypt.}

Received: 7 August 2020 Accepted: 15 November 2020

Published online: 25 November 2020

\section{References}

Abdelmohsen G, Dawoud GTM, Mohamed MSM (2020) Investigation of the biochemical and ultrastructural mechanisms underlying the antimicrobial activity of Mimusops spp. extracts. Baghdad Sci J 17:452-462

Aerts AM, Bammens L, Govaert G, Carmona-Gutierrez D, Madeo F, Cammue BPA, Thevissen K (2011) The antifungal plant defensin HsAFP1 from Heuchera sanguinea induces apoptosis in Candida albicans. Front Microbiol 2:1-9

Amin NTA, Abulreesh HH, El-Sheikh IA, Almaroai YA, Salem R, Osman GEH. Isolation and molecular characterization of a gene coding for defensin from an Egyptian maize hybrid (SC 168). The J. Anim. Plant Sci. 31(3):2021 (In press)

Balandin M, Royo J, Gómez E, Muniz LM, Molina A, Gueros G (2005) A protective role for the embryo surrounding region of the maize endosperm, as evidence by the characterization of ZmESR-6, a defensin gene specifically expressed in this region. Plant Mol Biol 58:269-282

Boman HG, Hultmark D (1987) Cell-free immunity in insects. Ann Rev Microbiol 41:41103-126

Chen GH, Hsu MP, Tan CH, Sung HY, Kuo CG, Fan MJ, Chen HM, Chen S, Chen CS (2005) Cloning and characterization of a plant defensin VaD1 from azuki bean. J Agric Food Chem 53:982-988. https://doi.org/10.1021/jf040 2227

Dixon RA (2001) Natural products and plant disease resistance. Nature 411(6839):843-847

Carvalho Ade O, Gomes VM (2009) Plant defensins_-Prospects for the biological functions and biotechnological properties. Peptides 30:1007-1020
CLSI 2012 Performance standards for antimicrobial disk susceptibility test: Approved atandard, Clinical and Laboratory Standars Institute - NCCLS.

Cociancich S, Bulet P, Hetru C, Hoffmann JA (1994) The inducible antibacterial peptides of insects. Parasitol Today 10:132-139

Cornet B, Bonmatin JM, Hetru C, Hoffmann JA, Ptak M, Vovelle F (1995) Refined three-dimensional solution structure of insect defensin A. Structure 3:435-448

Dowd PF, Johnson ET (2018) Overexpression of a maize (Zea mays) defensinlike gene in maize callus enhances resistance to both insects and fungi. Agri Gene 9:16-23

El-Gaied L, Mahmoud A, Salem R, Elmenofy W, Saleh I, Abulreesh H, Arif I, Osman G (2020) Characterization, cloning, expression and bioassay of vip3 gene isolated from an Egyptian Bacillus thuringiensis against whiteflies. Saudi J Biol Sci. https://doi.org/10.1016/j.sjbs.2019.12.013

Elgaied L, Salem R, Elmenofy W (2017) Expression of tomato yellow leaf curl virus coat protein using baculovirus expression system and evaluation of its utility as a viral antigen. 3 Biotech 7:269

Elmenofy W, Mohamed I, El-Gaied L, Salem R, Osman G, Ibrahim M (2020a) Expression of $1 \mathrm{~B}$ capsid protein of foot-and-mouth disease virus (FMDV) using baculovirus expression system and its validation in detecting SAT 2- specific antisera. Peer J 8:e8946. https://doi.org/10.7717/peerj.8946

Elmenofy W, Salem R, Osman E et al (2020b) Evaluation of two viral isolates as a potential biocontrol agent against the Egyptian cotton leafworm, Spodoptera littoralis (Boisd.) (Lepidoptera: Noctuidae). Egypt J Biol Pest Control 30:75. https://doi.org/10.1186/s41938-020-00276-3

Garcia-Olmedo F, Molina A, Alamillo JM, Rodrguez-Palenzuéla P (2015) Plant defense peptides. Peptide Sci 47:47479-491

Guilhelmelli F, Vilela N, Albuquerque P, Derengowski LI, Silva-Pereira da S, Kyaw CM (2013) Antibiotic development challenges: The various mechanisms of action of antimicrobial peptides and of bacterial resistance. Front Microbiol 4:1-12

Guillén-Chable F, Arenas-Sosa I, Islas-Flores I, Corzo G, Martinez-Liu C, Estrada G (2017) Antibacterial activity and phospholipid recognition of the recombinant defensin J1-1 from Capsicum genus. Protein Expr Purif 136:45-51

Guzmán-Rodríguez JJ, López-Gómez R, Salgado-Garciglia R, Ochoa-Zarzosa A, López-Meza JE (2016) The defensin from avocado (Persea americana var. drymifolia) PaDef induces apoptosis in the human breast cancer cell line MCF-7. Biomed Pharmacotherapy 82:620-627

Hultmark D, Steiner H, Rasmuson T, Boman HG (1980) Insect immunity Purification and properties of three inducible bactericidal proteins from hemolymph of immunized pupae of Hyalophora cecropia. Eur J Biochem 106:7-16

Kanost MR, Kawooya JK, Law JH, Ryan RO, Van Heusden MC, Ziegler R (1990) Insect haemolymph proteins. Adv Insect Physiol 22:299-396

Kant P, Liu WZ, Pauls KP (2009) PDC1, a corn defensin peptide expressed in Escherichia coli and Pichia pastoris inhibits growth of Fusarium graminearum. Peptides 30:1593-1599

Lacerda AF, Vasconcelos ÉAR, Pelegrini PB, Grossi de Sa MF (2014) Antifungal defensins and their role in plant defense. Front Microbiol 5:1-10

Lay FT, Anderson MA (2005) Defensins-components of the innate immune system in plants. Curr Protein Pept Sci 6:85-101

Montero-Alejo V, Acosta-Alba J, Perdomo-Morales R, Perera E, HernándezRodríguez EW, Estrada MP, Porto-Verdecia M (2012) Defensin like peptide from Panulirus argus relates structurally with beta defensin from vertebrates. Fish Shellfish Immunol 33:872-879

Mostafa SA, Mahmoud MS, Mohamed ZK, Enan MR (2009) Cloning and molecular characterization of chitinase from Bacillus licheniformis MS-3. J Gen Appl Microbiol 55:241-246

Noonan J, Williams WP, Shan X (2017) Investigation of antimicrobial peptide genes associated with fungus and insect resistance in maize. Int J Mol Sci 18:1938

Parisi K, Shafee TMA, Quimbar P, van der Weerden NL, Bleackley MR, Anderson MA (2019) The evolution, function and mechanisms of action for plant defensins. Semin Cell Dev Biol 88:107-118

Rodríguez-Decuadro S, Dans PD, Borba MA, Benko-Iseppon AM, Cecchetto G (2019) Gene isolation and structural characterization of a legume tree defensin with a broad spectrum of antimicrobial activity. Planta 250:1757-1772

Salem R, El-Kholy AA, Ibrahim M (2019) Eight novel single chain antibody fragments recognising VP2 of foot-and-mouth disease virus serotypes $A, O$, and SAT 2. Virology 533:145-154 
Salem R, Assem S, Omar AO, Khalil AA, Basry AM, Waly RF, Samir N, El-Kholy AA (2020) Expressing the immunodominant projection domain of infectious bursal disease virus fused to the fragment crystallizable of chicken IgY in yellow maize for a prospective edible vaccine. Mol Immunol 118C:132-141

Salem R, Arif Al, Salama M, Osman GH (2018) Polyclonal antibodies against the recombinantly expressed coat protein of the Citrus psorosis virus. Saudi J Biol Sci 25:733-738

Salem R, El-Kholy AA, Omar OA, Abu el-naga M N, Ibrahim M, Osman G (2019b) Construction, Expression and Evaluation of Recombinant VP2 Protein for serotype-independent Detection of FMDV Seropositive Animals in Egypt. Sci Rep 9:10135

Shafee TMA, Lay FT, Hulett MD, Anderson MA (2016) The defensins consist of two independent, convergent protein superfamilies. Mol Biol Evol 33:2345-2356

Singh AK, Dhanapal S, Yadav BS (2020) The dynamic responses of plant physiology and metabolism during environmental stress progression. Mol Biol Rep 47:1459-1470

van der Weerden NL, Anderson MA (2013) Plant defensins: Common fold, multiple functions. Fungal Biol Rev. https://doi.org/10.1016/j.fbr.2012.08.004
Wang B, Yu J, Zhu D, Zhao Q (2011) Maize defensin ZmDEF1 is involved in plant response to fungal phytopathogens. African J Biotechnol 10:16128-16137

Wei H, Movahedi A, Xu C, Sun W, Li L, Li D, Zhuge Q (2019) Characterization, expression profiling, and functional analysis of a Populus trichocarpa defensin gene and its potential as an anti-Agrobacterium rooting medium additive. Sci Rep 9:1-17. https://doi.org/10.1038/s41598-01951762-0

Yehia RS, Osman GH, Assaggaf H et al (2020) Isolation of potential antimicrobial metabolites from endophytic fungus Cladosporium cladosporioides from endemic plant Zygophyllum mandavillei. S Afr J Bot. https://doi. org/10.1016/j.sajb.2020.02.033

Zhang Y, Lewis K (2006) Fabatins: new antimicrobial plant peptides. FEMS Microbiol Lett 149:59-64

\section{Publisher's Note}

Springer Nature remains neutral with regard to jurisdictional claims in published maps and institutional affiliations.

\section{Submit your manuscript to a SpringerOpen ${ }^{\odot}$ journal and benefit from:}

- Convenient online submission

- Rigorous peer review

- Open access: articles freely available online

- High visibility within the field

- Retaining the copyright to your article

Submit your next manuscript at $\boldsymbol{\Delta}$ springeropen.com 